\title{
年頭の 辞
}

\section{軽 金 属 学 会 \\ 会長 中山一郎}

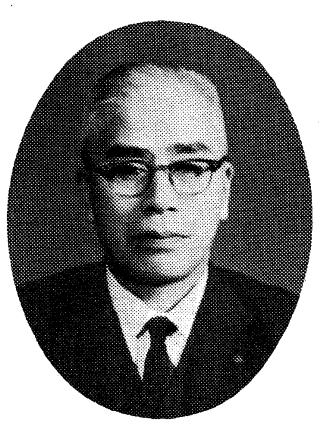

会員の皆様，新年明けましておめでとらございます。

新年を迎えるに当って昨年 1 年間の本学会の活動をふりかえって見ますと，厳しい経済環境下のもと で，「軽金属」誌の発行，春秋の研究発表大会の開催，研究委員会各部会の活動を基調に，シンポジウ ム，講習会などを実施してまいりました。とくに発足間もない研究委員会におきましては，既設の鋳造 ・凝固，金属加工，金属成形ならびに表面処理の 4 部会に加え材料・物性部会を新設し 5 部会となり， 各部会とも学界の若手研究者が中心となり、当面する学術的，技術的諸問題に関し，真剣な討論を繰り 返えした後，具体的問題を取り上げるなど，部会活動は軌道に乗りはじめたといえましょら。今年はこ れらの成果がかなり期待されるところであります。また，一昨年の第13回定時総会を機に評議員制度を 新たに導入し，昨年の第14回定時総会において42名の評議員が選任され，本学会発展のためそれぞれの 專門分野でご助力いただくことになりました。維持会員の加入については財務委員の諸先生方のご尽力 ならびにご加入いただいた会員会社のご理解あるご援助により逐次会員数が増えていることは本学会運 営に対して多くの方々のご支援の賜物と，感謝にたえません。表彰関係では高橋記念賞が新設され，そ の第 1 回受彰者 4 名が11月28日秋期大会の際，軽金属論文賞，小山田記念賞受賞者とともに表彰されま した。この高橋記念賞は今後毎年，年 1 回アルミニウム及びアルミニウム合金の鋳物関連の技能職を対 象に贈られることになっておりますので，平素生産現場で地道に技術改善，作業改善などに努力されて いる方々を今後とも地区センターを通じご推薦いただき，この賞をより一層意義深いものと致したいと 存じます。

さて，昨年のわが国アルミニウム産業界についてみますと，軽金属圧延，加工製品ならびに最終製品 の各分野におきましては，かなりの需要拡大基調を示し，昭和53年度におけるアルミニウム需要見通し では，昭和52年の 208 万トンを上わる約 225 万トン（前年比 $8.1 \%$ 増）と戦後最高の水準に達する 見込み でありまして，企業体質改善に大きく寄与したのであります。しかし，製鍊業界におきましては，円相 場の急騰により，ますます苦境に陥り，産業構造審議会アルミニウム部会が一昨年に引続き開催され， アルミニウム製鍊工業における構造改善の方向についての提言を受け，これら諸対策を十分に論議した 上で，需要業界のコンセンサスを得るとともに，政府の援助を仰いで，わが国製錬業が立直りのきっか けをつかむよう努力致しているところであります。 
以上のような状勢のもとで，本学会に課せられた使命は極めて重大なものがあり，軽金属業界全体の 再建をはかるに当って，各位におかれては，やはり基礎理論に立脚した新技術の開発，新規需要の開拓 をより積極的に促進しなければならないことは自明の理で，研究開発にたずさわっておられる方々は， 総力結集のもとにより広い視野に立って新しい展開をされることが必要と存じます。

本学会の本年度の目標は，一層活発に研究活動を実施するとともに高エネルギー時代の要請に応じ研 究内容をより高度化し，一領域の学問のみでは解決できないような問題については 各専門分野の方々の 知識の集積，あるいは他学会との協調体制をとり，学界，業界が一体となって研究成果をあげるととも に，産業界への実効をあげるべく，会員各位のご指導ご協力とご助言を賜わりながら最大限の努力を傾 注致す所存であります。 